\title{
Mapeamento dos Recursos Minerais da APA da Bacia Hidrográfica do Rio Machado Associado aos Riscos Ambientais de Mineradoras Irregulares
}

\author{
Mineral Resources Mapping of the APA of the Machado River Hydrographic Basin \\ Associated with Irregular Mining Environmental Hazards
}

Luiz Carlos dos Santos Júnior Graduando em Geografia pela UNIFAL - MG, Brasil luiz.jr22@hotmail.com

Lineo Aparecido Gaspar Junior Doutor em Geologia Regional pela UNESP Rio Claro Professor na UNIFAL - MG, Brasil

lineo.gaspar@unifal-mg.edu.br

Caio Faria da Cunha Barbosa Adorno Graduando em Geografia pela UNIFAL - MG, Brasil caioadorno31@gmail.com

Marcius Vinicius Ver Valen Cruz Graduando em Geografia pela UNIFAL - MG, Brasil marciusvi@yahoo.com.br

\begin{abstract}
Resumo
Os recursos minerais presentes na APA da Bacia Hidrográfica do Rio Machado são bens passíveis de exploração e, consequentemente, resultam em danos ambientais irreversíveis quando detectadas mineradoras em situações irregulares. Dessa forma, é imprescindível o mapeamento desses recursos para diagnosticar as irregularidades e os riscos ambientais correlacionados às intervenções antrópicas de cunho extrativista. O objetivo do trabalho consiste na elaboração de documentos cartográficos para identificar os recursos minerais presentes na área de estudo e apontar os riscos ambientais consoantes às mineradoras irregulares. A pesquisa buscou identificar a disponibilidade dos recursos minerais e as áreas de extração através dos trabalhos de campo e ensaios laboratoriais. Os dados obtidos, fomentaram o georreferenciamento mediante os softwares ArcGIS 10.6.1 e SPRING 5.5.3 utilizando imagens do satélite CBERS-4, embasados no fundamento teórico de acervos literários como revistas, jornais e livros pelo portal de periódicos. Os resultados analisados viabilizaram o reconhecimento de impactos ambientais negativos gerados pela exploração irregular desses recursos facultando a orientação de órgãos públicos como as gestões municipais e as entidades governamentais como o Departamento Nacional de Produção Mineral (DNPM) no desconhecimento de atividades minerárias em exercício.
\end{abstract}

Palavras-chave: mineradoras ilegais, produção mineral, impactos ambientais, recursos naturais

\begin{abstract}
The mineral resources present on APA of Hydrographic Basin of the Machado's River are assets capable of exploration and, consequently, results in irreversible environmental damage when detected mining companies in irregular situations. In this way, its indispensable the mapping of these resources to diagnose irregularities and environmental risks related to anthropogenic interventions of an extractive nature. The purpose of the work consists in the elaboration of cartographic documents to identify the mineral resources presents in the study area and appoint the
\end{abstract}


environmental risks consonant to irregular miners. The research sought to identify the availability of mineral resources and the extraction areas through fieldwork and laboratory essays. The data obtained promoted the georeferencing through the software ArcGIS and SPRING 5.5.3 using CBERS-4 satellite images, based on the theoretical basis of literary collections such as magazines, newspapers and books through the journal portal of periodicals. The results analysed enabled the recognition of adverse environmental impacts engendered by the irregular exploration of these resources empowering the guidance of public agencies such as municipal management and government entities, like the National Department of Mineral Production (NDMP), in the ignorance of mining activities in practice.

Keywords: illegal mining, mineral production, environmental impacts, natural resources

\section{INTRODUÇÃO}

O intuito exploratório de recursos minerais surge devido às demandas do mercado interno e externo e o DNPM (Departamento Nacional de Produção Mineral) é o órgão responsável pelo planejamento, licenciamento e supervisão de exploração mineral. As consequências recorrentes da grande procura de bens minerais resultam em explorações ilegais, isto é, sem a devida concessão do DNPM. Ao longo da pesquisa, foram encontradas inúmeras atividades exploratórias em exercício, sugerindo o funcionamento ilegal dada à infraestrutura precária e improvisada. Tais intervenções são catastróficas quando analisadas em um quadro ambiental e social desequilibrado. Portanto, o licenciamento do DNPM visa não apenas a extração de recursos minerais de maneira adequada, mas também o plano de recuperação de áreas degradadas após o término das atividades.

A terminologia denominada "risco ambiental" utilizada pela pesquisa está arreigada no conceito abordado por Dagnino e Carpi Junior (2007), ao descrever os riscos ambientais como sendo as situações de perigo de danos em seu sentido amplo, em vertentes ambientais, sociais e tecnológicos, seja no meio natural ou no meio construído pelo homem. As autoras, Yvette Veyret e Nancy Meschinet Richemond (2007), corroboram ao alegar que os riscos ambientais "resultam da associação entre os riscos naturais e os riscos decorrentes de processos naturais agravados pela atividade humana e pela ocupação do território.” (VEYRET; RICHEMOND, 2007, p. 63).

A priori, o presente estudo tem como finalidade a análise das distintas composições mineralógicas da região, verificadas em campo e em ensaios laboratoriais, ensejando a classificação dos minerais que compõem a área e possibilitando um diagnóstico acurado da disponibilidade desses bens naturais a fim de delimitá-los segundo sua ocorrência. Ademais, devem-se ressaltar os impactos ambientais gerados pela exploração desses recursos uma vez que tais ações podem causar danos à população e a fauna e flora da região. 


\subsection{OBJETIVOS}

- Elaborar documentos cartográficos que visem o levantamento de recursos minerais presentes na APA do Rio Machado;

- Identificar através de análises petrológicas os minerais presentes na área de estudo a partir dos ensaios laboratoriais;

- Apontar os riscos ambientais ligadas às mineradoras irregulares identificadas em campo.

\section{2. ÁREA DE ESTUDO}

A APA da Bacia Hidrográfica do Rio Machado engloba os municípios de Machado, Poço Fundo, Alfenas, Fama, Congonhal, Espírito Santo do Dourado, Ipuiúna, São João da Mata, Campestre, Paraguaçu e Carvalhópolis, localizadas nas microrregiões de Alfenas, Pouso Alegre, Santa Rita do Sapucaí e Poços de Caldas, do Estado de Minas Gerais (Figura 1), com extensão territorial de 117, 4 mil hectares (IEF-MG, 2019).

Segundo Lucas Emanoel Servidoni e Clibson Alves dos Santos (2014) os valores altimétricos do Rio Machado são de 1478 metros em amplitudes máximas e 765 metros em amplitudes mínimas. Assim, tornam-se perceptíveis as descontinuidades ao longo dos perfis morfológicos da paisagem, acentuando altitudes elevadas na porção central da Bacia Hidrográfica do Rio Machado e rupturas abruptas do relevo no trecho baixo e alto da rede hidrográfica. Os autores, Henrique Correa Lima et al. (2010) denotam que o Rio Machado sofreu um processo de soerguimento em seu alto curso da direção norte-sul para a direção sudoeste- nordeste, acarretando tais descontinuidades. As características físicas como a textura e estruturas dos solos e das rochas indicam os diferentes fatores que envolvem a suscetibilidade à erosão, resistência ao intemperismo e a drenagem do corpo hídrico, que influenciam diretamente no desempenho da bacia hidrográfica e na morfologia dos perfis. 


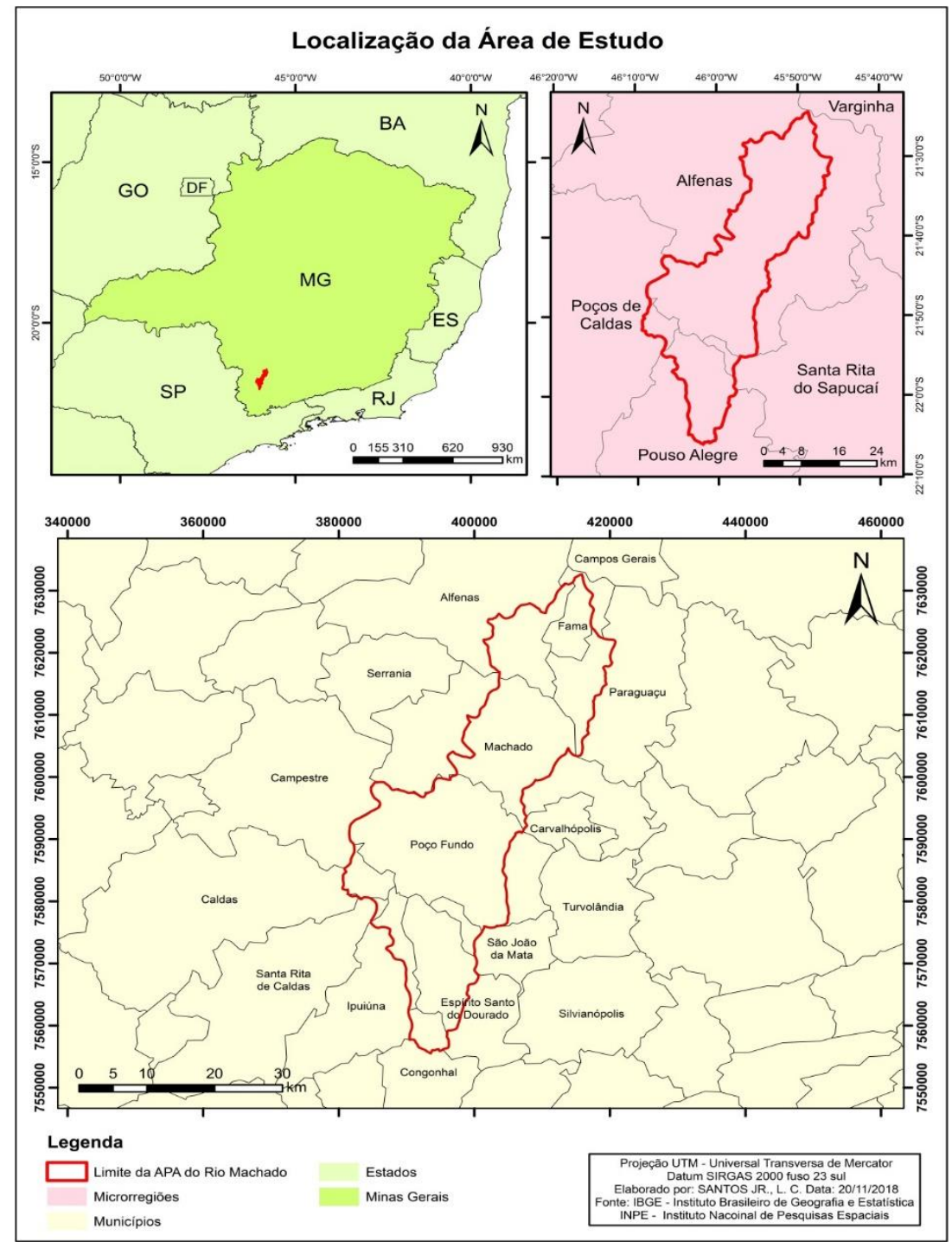

Figura 1. Localização da Área de Estudo.

Fonte: Acervo Pessoal.

\section{IMPACTOS AMBIENTAIS}

O crescimento populacional das últimas décadas repercutiu na crescente demanda de recursos naturais, aumentando-a desenfreadamente. Segundo Bernardo Barbosa et al. (1999), a utilização de materiais geológicos se iniciou com a pedra lascada com os hominídeos e, posteriormente, a descoberta do ferro, bronze e finalmente a exploração de recursos em aplicações energéticas e industriais. No decorrer dos anos, as técnicas foram sendo aprimoradas e, com isso, a demanda de recursos minerais pelo mercado cresceu concomitante aos avanços tecnológicos. Paradoxal e simultaneamente, o aumento de tais explorações geraram impactos nas esferas sociais, econômicas, culturais e ambientais.

Segundo Luis Enrique Sánchez (2006), os impactos ambientais são definidos como o resultado de ações humanas e podem ser divididos em positivos e negativos. Assim, os impactos 
positivos são aqueles que compreendem os efeitos benéficos ao ser humano e ao meio ambiente como, por exemplo, o tratamento de efluentes domésticos que proporcionam a melhoria na saúde pública e na qualidade dos corpos hídrico. Os impactos negativos abarcam os processos prejudiciais que envolvem o meio natural como, por exemplo, o despejo de efluentes industriais em um corpo hídrico. Assim, quando associados às áreas estudadas, os impactos ambientais são visivelmente negativos. A maior problemática identificada é a preponderante presença de solos expostos, quando submetidos à exploração mineral, que são abandonados sem qualquer medida de recuperação, favorecendo o aparecimento de problemas ambientais graves como, por exemplo, sulcos erosivos, assoreamento de corpos hídricos e os movimentos de massa (em declividades acentuadas).

Os autores Jurandyr Luciano Sanches Ross e Marcos Estevan Del Prette (2011), elucidam que as paisagens não são estáticas e estão em constante transformação de acordo com o meio ao qual estão inseridas, sendo o homem um importante agente transformador da paisagem. Os elementos que compõem a paisagem possuem dinâmicas diferentes e são continuamente moldadas pelos agentes físicos, químicos, físico-químicos e biológicos, sendo naturais ou antrópicos. Logo, é imprescindível o diagnóstico e prognóstico de áreas que possuem recursos minerais disponíveis para exploração, pois os impactos negativos gerados a partir da extração de bens minerais podem atingir direta e ou indiretamente o meio ambiente. Segundo Sánchez (2006) os impactos ambientais diretos são produtos de ações primárias que causem o efeito nocivo ao meio natural e os impactos ambientais indiretos são os efeitos secundários decorrentes das ações diretas às esferas sociais, econômicas, culturais e ambientais. Com isso, o uso antrópico dos bens minerais detectados na APA do Rio Machado necessitam de monitoramento e fiscalização recorrente para que não haja nenhum risco de desequilíbrio ambiental nessas áreas.

\section{MATERIAIS E MÉTODOS}

A etapa fundamental e imprescindível, inicialmente, se dá na fundamentação teórica. A etapa em questão consiste na compreensão e análise de textos publicados sobre os municípios pesquisados e sobre a Bacia Hidrográfica do Rio Machado. Logo, as informações obtidas através do levantamento bibliográfico evidenciaram componentes necessários para estabelecer o planejamento de pesquisas relacionadas aos temas acerca dos aspectos físicos da região que compreende a APA da Bacia do Rio Machado. Por conseguinte, o trabalho de campo tornou-se crucial para a realização do estudo, sendo a área visitada constantemente sob a supervisão do orientador durante o período de 12 (doze) meses. A análise empírica e coleta de amostras ocorreram nos períodos que sucederam a fundamentação teórica e a seleção de pontos de interesse, que corresponderam as áreas de fácil 
acesso e limítrofes aos relevos acentuados e rupturas abruptas de cotas altimétricas, identificadas nas seis cartas topográficas em escala 1:50.000, sendo elas: Campestre, Machado, Rio Capivari, Poço Fundo, Ipuíuna e Pouso Alegre. Por fim, a etapa final se sucede na confecção dos documentos cartográficos em alicerce aos resultados obtidos pelo estudo (Figura 2).

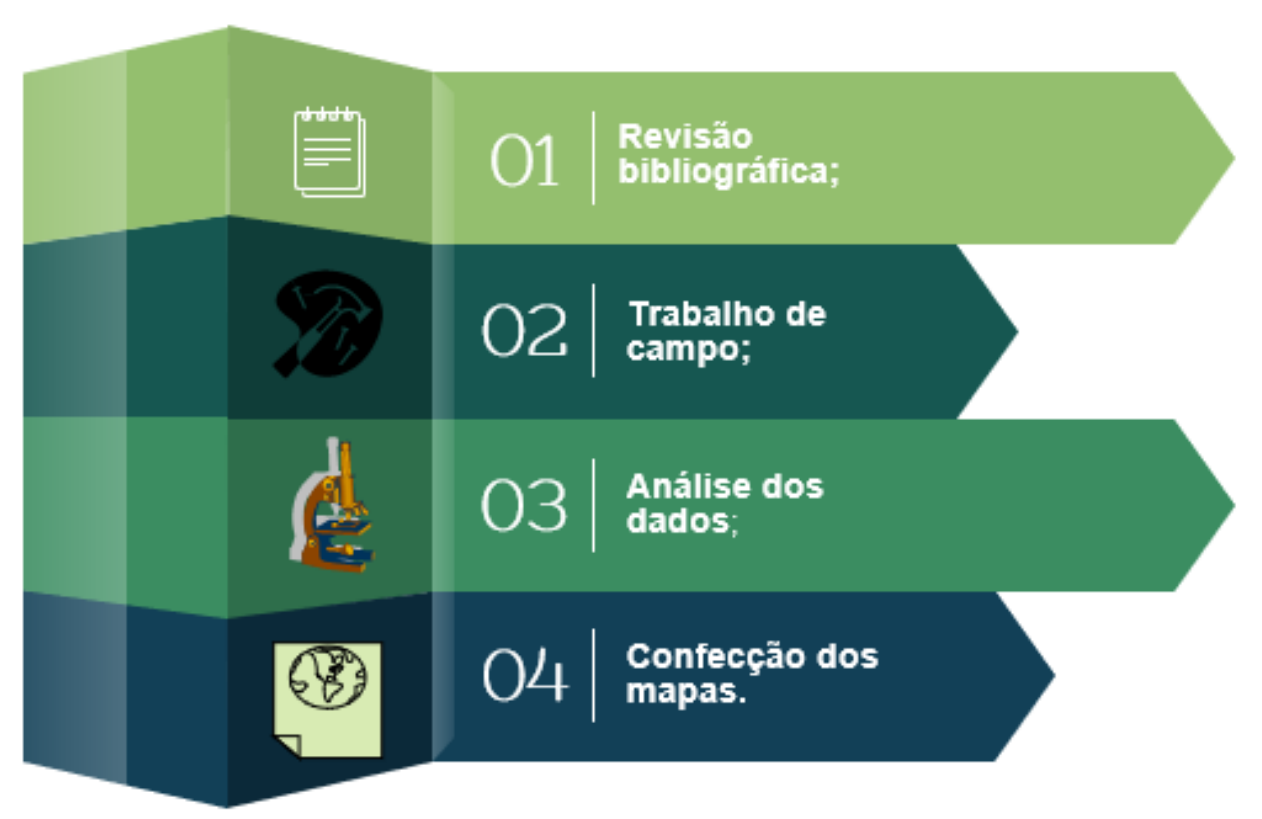

Figura 2. Fluxograma da Metodologia utilizada no presente trabalho.

Para a caracterização do material litológico, a metodologia utilizada foi baseada nos Ensaios Químicos e Geotécnicos em Solos de Lineo Aparecido Gaspar Junior (2011) e no Manual de Métodos de Análise de solo, da Embrapa (2011). Os ensaios adotados como: a descrição macroscópica, microscópica (estereoscópica), o índice de umidade e teor de matéria orgânica no solo (carbono orgânico), índice de plasticidade e de $\mathrm{pH}$ e distribuição granulométrica foram devidamente realizados no Laboratório de Geociências da Universidade Federal de Alfenas (UNIFAL/MG). Os atributos foram divididos em: Trabalhos de campo para a coleta de amostra, análise empírica das feições geológicas e geomorfológicas da área em questão e ensaios físicos dos minerais em campo (Cor, formato dos grãos, esfericidade, granulometria, plasticidade, concentração de matéria orgânica, associação mineral e observações), estruturados na ficha de campo (Figura 3).

A ficha de campo elaborada para o referente estudo consistiu em descrever 36 (trinta e seis) pontos de coleta. Os dados compreendem o limite municipal pertencente à amostra coletada; as coordenadas (x, y) em Projeção UTM (Universal Tranversa de Mercator); a descrição da amostra classificadas quanto à esfericidade dos grãos (baixa e alta), o formato dos grãos (bem arredondado, arredondado, subarredondado, subanguloso, anguloso e bem anguloso), granulometria (fina, média e grossa), plasticidade (não plástica, ligeiramente plástica, plástica e muito plástica), concentração 
de matéria orgânica (ausente, muito baixa, baixa, média, alta e muito alta), associação mineral, cor dos grãos e observações.

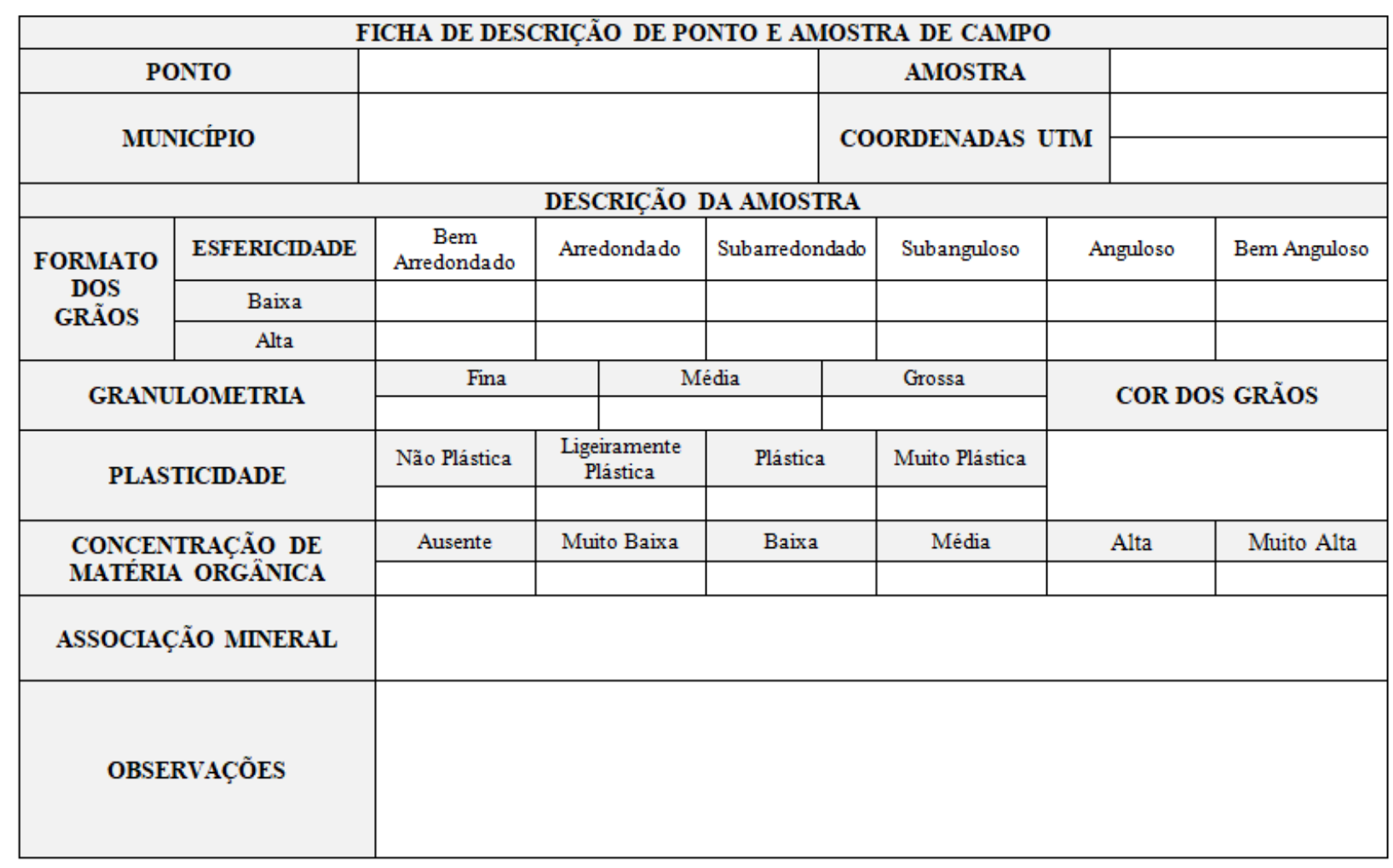

Figura 3. Ficha de descrição de ponto utilizada em campo.

Fonte: Acervo Pessoal, 2019.

Ao final da pesquisa, foram elaborados 3 (três) documentos cartográficos, sendo eles: o mapa da coleta de amostras, de recursos minerais identificados e o de riscos ambientais. Os mapas foram produzidos através dos softwares SPRING 5.5.3 e ArcGIS 10.6.1. Foram obtidas imagens do satélite CBERS-4 fornecidas pelo portal do INPE (Instituto Nacional de Pesquisas Espaciais) e, posteriormente, georreferenciadas. Os dados obtidos através do estudo forneceram acervo literário imprescindível, apontando a disponibilidade de bens minerais para prefeituras e empresas, auxiliando o monitoramento às políticas de licenciamento de exploração de recursos minerais e, além disso, poderá dar vazão à elaboração de estudos mais aprofundados decorrentes deste trabalho.

\section{RESULTADOS}

Durante o período de doze meses, foram realizados 8 (oito) trabalhos de campo, uma parceria da Universidade Federal de Alfenas com IEF (Instituto Estadual de Florestas) de Minas Gerais. Os 36 (trinta e seis) pontos de coleta, possibilitaram a elaboração da localização dos recursos minerais identificados segundo as coordenadas UTM (x,y) fornecidas pelo aparelho GPS. 
Os pontos foram numerados de 1 a 36, seguindo a ordem de coleta, nos limites municipais de Poço Fundo, Campestre, Carvalhópolis, Alfenas, Machado, São João da Mata, Ipuiúna, Congonhal e Espírito Santo do Dourado-MG.

Os pontos de maior relevância foram demarcados nas seis cartas topográficas (escala 1:50.000) durante a etapa de planejamento e seguiram critérios como, por exemplo, a diferença abrupta de cota altimétrica entre dois relevos, a proximidade dos relevos com a bacia hidrográfica e geomorfologias distoantes (serras, morros, colinas e planícies) em conformidade com a facilidade de acesso (rodovias, estradas pavimentadas ou não e pontes. Assim, os materiais coletados e suas respectivas coordenadas resultaram no Mapeamento de Coleta de Amostras (Figura 4).

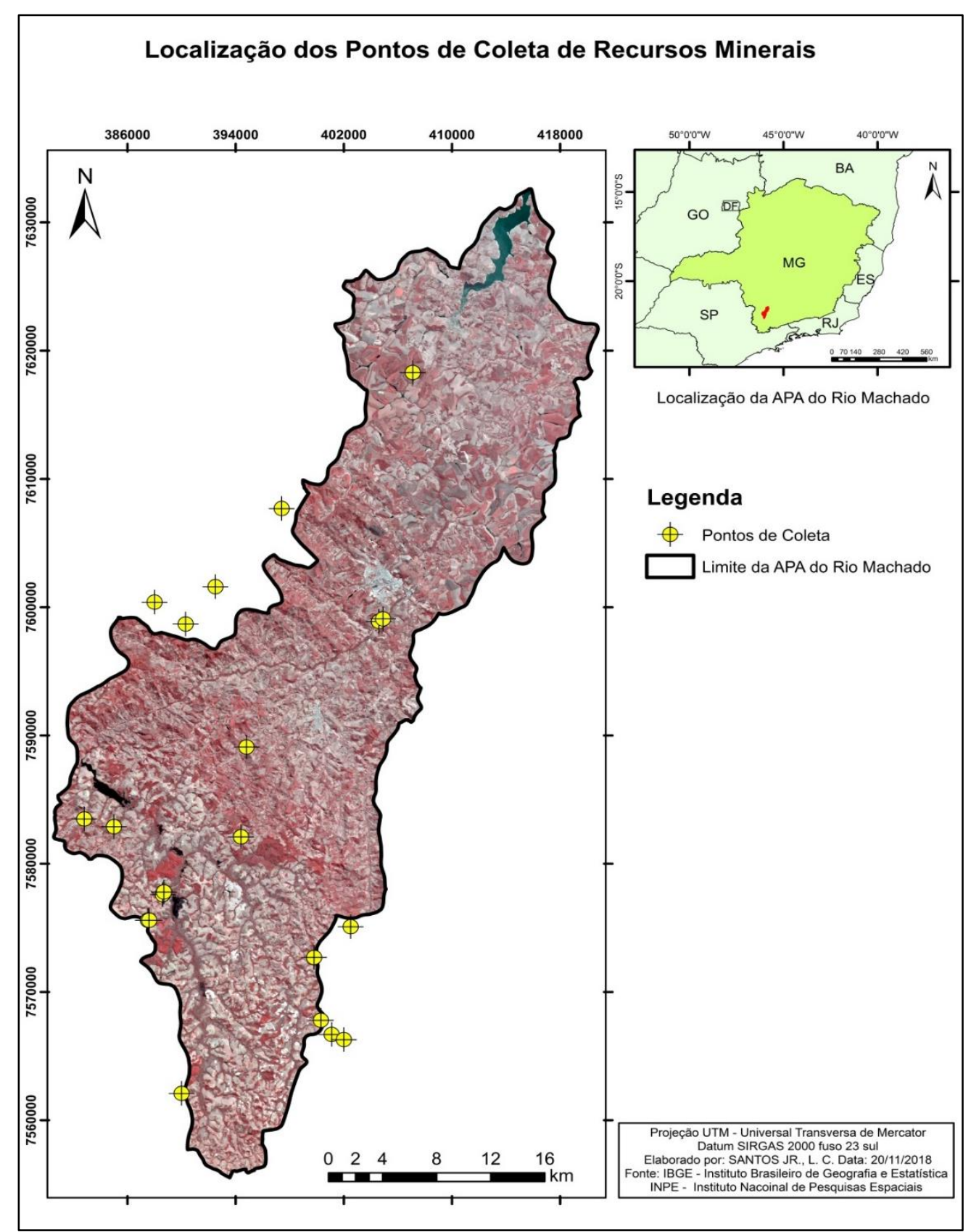

Figura 4. Mapa de Localização de Pontos de Coleta. Fonte: Acervo Pessoal, 2019. 
Os aspectos físicos e a composição mineralógica das amostras viabilizaram a identificação e, consequentemente a classificação empírica dos materiais encontrados, sendo eles: argila, areia, areia vermelha, cascalho, hiperstênio gnaisse, granada biotita gnaisse, biotita granito, biotita gnaisse, migmatito, gnaisse migmatítico, granito migmatítico, granito porfiróide, granito e gnaisse (Tabela 1).

Tabela 1. Identificação dos tipos de rochas e minerais encontrados por município.

\begin{tabular}{|c|c|c|c|}
\hline Coordenadas X & Coordenadas Y & Municípios & Amostras \\
\hline 038980 & 7585500 & \multirow{7}{*}{ Poço Fundo } & Argila \\
\hline 038940 & 7585300 & & Areia Vermelha \\
\hline 038760 & 7591600 & & Areia \\
\hline 040110 & 7590400 & & Areia Vermelha \\
\hline 039480 & 7589100 & & Gnaisse Migmatítico \\
\hline 038640 & 7582000 & & Granito Migmatítico \\
\hline 039440 & 7582100 & & Granito \\
\hline 038680 & 7584900 & \multirow{7}{*}{ Campestre } & Areia \\
\hline 038800 & 7600400 & & Granito Porfiróide \\
\hline 039030 & 7598700 & & Gnaisse Migmatítico \\
\hline 039250 & 7601600 & & Granito \\
\hline 038610 & 7581000 & & Gnaisse \\
\hline 038500 & 7582900 & & Gnaisse \\
\hline 038280 & 7583500 & & Gnaisse \\
\hline 040940 & 7590100 & \multirow{2}{*}{ Carvalhópolis } & Argila \\
\hline 041240 & 7591100 & & Cascalho \\
\hline 040180 & 7626200 & \multirow{2}{*}{ Alfenas } & Hiperstênio Gnaisse \\
\hline 040270 & 7623000 & & Granada Biotita Gnaisse \\
\hline 040290 & 7610800 & \multirow{6}{*}{ Machado } & Migmatito \\
\hline 040210 & 7602700 & & Gnaisse \\
\hline 039740 & 7607700 & & Cascalho \\
\hline 040460 & 7598900 & & Areia Vermelha \\
\hline 040490 & 7599100 & & Argila \\
\hline 040710 & 7618300 & & Granito Migmatítico \\
\hline 040250 & 7575100 & \multirow{5}{*}{ São João da Mata } & Migmatito \\
\hline 039980 & 7572700 & & Gnaisse Migmatítico \\
\hline 039980 & 7569000 & & Cascalho \\
\hline 040030 & 7567800 & & Gnaisse \\
\hline 040110 & 7566700 & & Gnaisse \\
\hline 038750 & 7575600 & \multirow{4}{*}{ Ipuiúna } & Biotita Gnaisse \\
\hline 038860 & 7577600 & & Granito \\
\hline 038760 & 7575600 & & Granito Migmatítico \\
\hline 038870 & 7577800 & & Biotita Granito \\
\hline 039000 & 7562100 & \multirow{2}{*}{ Congonhal } & Cascalho \\
\hline 039210 & 7580300 & & Biotita Gnaisse \\
\hline 040200 & 7566300 & Espírito Santo do Dourado & Migmatito \\
\hline
\end{tabular}

Em campo, podemos destacar os trechos percorridos durante a pesquisa e destacá-las de acordo com os municípios visitados. No trecho baixo da APA do Rio Machado, pertencente aos limites municipais de Alfenas, foram identificadas rochas granada biotita gnaisse em uma pedreira a céu aberto (abandonada). A rocha apresentou dobramentos simétricos no maciço, de 
aproximadamente 20 metros de altura. Os grãos minerais possuem baixa esferecidade, granulometria média a grossa e não plástica, ausência de matéria orgânica e cor dos grãos pretos/vermelhos/acinzentados. Os minerais identificados foram: quartzo, feldspato, granada, biotita e piroxênios. Outro local visitado foi o ponto turístico conhecido popularmente como "Pedra", um afloramento do maciço rochoso de hiperstênio gnaisse. O formato de grãos sub-angulosos com esfericidade baixa, granulometria média, não plástica, concentração de matéria orgânica ausente e cor dos grãos esverdeados. A rocha expôs características de intemperização severa devido à exposição do afloramento do maciço. Os minerais identificados foram: quartzo, feldspato, hiperstênio, plagioclásio, biotita e piroxênios.

No município de Machado, foram identificados pontos de exploração de gnaisse granítico (migmatito), com presença do mineral caulinita em alguns pontos, apresentando furos e cortes na rocha - resquícios de explorações anteriores - com matacões aflorados bastante erodidos pelos processos intempéricos. O formato dos grãos angulosos com esfericidade baixa, granulometria média a grossa e não plástica, a concentração de matéria orgânica baixa e cor dos grãos pretos e com pontos avermelhados pela oxidação e em alguns pontos, brancos. Os minerais identificados: quartzo, feldspato, plagioclásio, biotita e muscovita. Também foram encontradas rochas: gnáissicas, granito migmatítico; argilas, cascalho e areia vermelha - advindos de filossilicatos e tectossilicatos.

Nos limites municipais de Poço Fundo, localizado no trecho médio da Bacia do Rio Machado, a presença de bancos de argila com plasticidade relativa (média-alta), cor acinzentada relacionada à gleissolos próximos da planície de inundação da área. Os grãos arredondados têm esfericidade baixa, a granulometria fina e ligeiramente plástica, cor acinzentada e amarelada com alto teor de matéria orgânica. Os minerais encontrados foram: argilominerais e quartzo. Em outro local foram encontrados bancos de extração de areia em relevos mais suavizados, com grãos de esfericidade baixa em formatos sub-angulosos, a granulometria média e não plástica, a cor dos grãos avermelhados/amarelados com ausência de matéria orgânica. Os minerais presentes foram: quartzo e feldspato (ortoclásio e plagioclásio); também foi identificada a extração de areia vermelha (gnaisse) em taludes artificiais com horizonte $\mathrm{C}$ exposto (saprolito), próximo à rodovia entre os limites municipais de Poço Fundo e Machado, com o formato dos grãos bem arredondados com esfericidade alta, a granulometria fina a média e ligeiramente plástica, a concentração de matéria orgânica baixa e a cor dos grãos avermelhados. Os minerais encontrados: quartzo, feldspato e filossilicatos. Além disso, foram identificadas as rochas: gnaisse migmatítico, granito migmatítico e granito porfiróide.

$\mathrm{Na}$ área compreendida pelo município de Campestre que abrange a extensão da APA do Rio Machado, foi caracterizada a extração de areia por maquinários e caminhões nas margens do 
Rio Machado com alto risco de impacto ambiental negativo. Nesse ponto, o formato dos grãos é arredondado com esfericidade alta e granulometria fina a média, não plástica e com concentração de matéria orgânica mediana, a cor dos grãos claros em tons esbranquiçados/bege. Os minerais são: quartzo, feldspato e anfibólio. Foram encontrados também afloramentos rochosos de granito porfiróide próximos à estrada rural, apresentando pouca intemperização em porções de matacões e seixos ao longo da estrada. O formato dos grãos bem angulosos e não pláticos, a granulometria grossa com concentração muito baixa de matéria orgânica. Os minerais identificados foram: quartzo, biotita e ortoclásio. Outras rochas como o gnaisse, o granito e o gnaisse migmatítico também foram identificadas nessa região.

O município de Carvalhópolis apresentou características semelhantes aos aspectos geológicos e pedológicos de Campestre, resultando na identificação de argilas e areias ao longo do trajeto. Foi identificada a extração de argila para a construção de um poço de dessedentação do gado, próximo ao maciço rochoso em uma área de pastagem. Nesse ponto, os grãos minerais são sub-arredondados com esfericidade baixa, granulometria fina, plasticidade muito alta e a cor dos grãos acinzentados. Os minerais: argilominerais, quartzo, além do alto teor de matéria orgânica. Outro ponto foi à extração de cascalho próximo ao Parque Municipal de Carvalhópolis. Nesse local, o formato dos grãos são sub-arredondados com esfericidade baixa, granulometria média a grossa e não plástica, a concentração de matéria orgânica é baixa e a cor dos grãos são brancos/avermelhados/amarelados. Os minerais observados: quartzo, caulinita e argilominerais.

Nos pontos que compreendem os limites municipais de São João da Mata, foram identificados paredões rochosos, um ponto turístico conhecido como "Parque Pedra Navio", extração de cascalho e potenciais pedreiras de rochas gnaisses migmatíticos. As principais observações apontadas são os afloramentos rochosos (matacões) e a extração de cascalho (caulinita), próximos às estradas. Foram observadas propriedades como a granulometria média a fina e o formato dos grãos bem angulosos e não plásticos, a cor dos minerais brancos, pretos e rosados/avermelhados com concentração mediana a alta de matéria orgânica na rocha ou em seu entorno (processos intempéricos biológicos). Os mineirais encontrados foram: quartzo, feldspatos (ortoclásio e plagioclásio) e biotita.

Nos municípios de Espírito Santo do Dourado e Congonhal, localizados no alto trecho da Bacia Hidrográfica do Rio Machado, a diferença geológica proporcionou a caracterização dos recursos minerais distintos, mesmo sendo muito próximas. Embora a composição mineralógica seja muito semelhante, a variação no metamorfismo resultou em diferentes tipos de rochas. A rocha granito migmatítico coletada, encontrada no município de Espírito Santo do Dourado, advém de afloramentos rochosos próximos à estrada de terra e apresenta orientação (direção do 
metamorfismo). Propriedades como o formato dos grãos são bem angulosos, a granulometria fina a média e não plástica, a cor dos grãos preto, branco e avermelhado com ausência de matéria orgânica, foram destacadas. Os minerais identificados são: quartzo, biotita e ortoclásio. Os limites municipais de Congonhal e Ipuiúna apresentam características distintas, sendo predominadas por rochas biotitas gnaisses com graus de variação para biotita xisto. Nesses pontos, veios de quartzo são comumente encontrados na estrada e blocos e matacões em afloramento. O formato dos grãos são sub-angulosos, a granulometria entre fina e média e a plasticidade baixa, a cor dos grãos são basicamente pretos e esbranquiçados e ausência de concentração de matéria orgânica. Os minerais encontrados são: biotita, quartzo e feldspato (ortoclásio e plagioclásio).

Por fim, o município de Ipuiúna, apresenta a variação de granito, biotita granito, granito migmatítico e biotita gnaisse. Estas rochas afloram nas estradas em forma de blocos e matacões em terrenos extensos, cobertos de vegetação rasteira e arbórea. Algumas dessas rochas apresentam foliação esferoidal em conjunto de corpos hídricos. O formato dos grãos são bem angulosos e granulometria média, a plasticidade é ausente e a cor dos grãos são pretos e brancos, a concentração de matéria orgânica é muito baixa e os processos intempéricos do tipo biológico alteraram bastante as rochas. Os minerais encontrados foram: quarzto, biotita, feldspato (sódico e potássico), e piroxênio. As ações antrópicas são intensas e, consequentemente, geram mudanças significativas na paisagem.

Para as análises laboratoriais, foram selecionadas a amostragem de 10 (dez) pontos de coleta de solos e rochas para a realização de ensaios de granulometria, análise microscópica, carbono orgânico, índice de pH e plasticidade. Os ensaios em microscopia (aumento de 50x) revelaram a presença predominante de grãos de quartzo (por vezes, grãos com faces bem definidas), minerais ferromagnesianos, piroxênios, anfibólios e minerais aluminossilicatos como biotita e muscovita; além de feldspatos potássicos e sódicos (Figura 5).

Os índices de carbono orgânico variaram de 4-8\%, caracterizando assim, um solo com baixo teor da matéria orgânica e demarcado pelo excesso de íons $\mathrm{Al}^{3+}$ e $\mathrm{H}^{+}$ligados aos colóides do solo, tornando-o altamente ácido. Os índices de potencial hidrogeniônico atestaram tal afirmação uma vez que o pH foi de 4 a 4,8, caracterizando acidez alta (Tabela 2). 


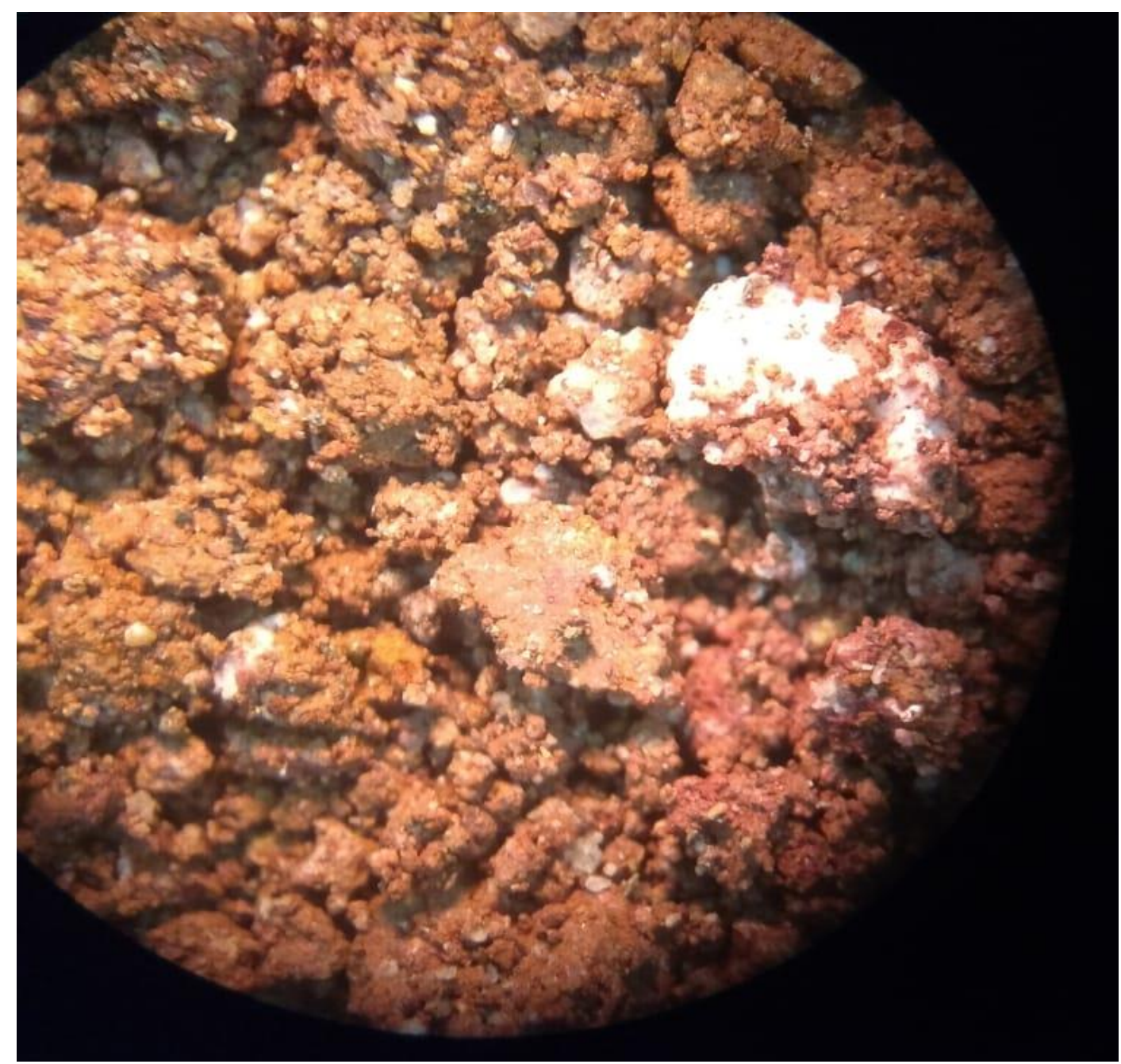

Figura 5. Solo coletado no Ponto 18, no município de São João da Mata, sob análise macroscópica. Fonte: Dados da Pesquisa

Tabela 2. Índice de pH e Carbono Orgânico no solo.

\begin{tabular}{ccc}
\hline Amostras & $\mathbf{p H}$ & $\begin{array}{c}\text { Carbono } \\
\text { Orgânico (\%) }\end{array}$ \\
\hline 1 & 4,5 & 6,8 \\
2 & 4,5 & 5,6 \\
3 & 4,8 & 7,1 \\
4 & 4,0 & 4,0 \\
5 & 4,5 & 5,0 \\
6 & 4,2 & 5,4 \\
7 & 4,4 & 7,2 \\
8 & 4,8 & 4,9 \\
9 & 4,3 & 8,0 \\
10 & 4,4 & 4,9 \\
\hline
\end{tabular}

Fonte: Dados da Pesquisa 
Os índices de umidade resultaram na variação de 18 a 40\%, aproximadamente - apontando baixo teor de umidade, uma vez que as dez amostras selecionadas foram coletadas em climas secos e quentes. Por fim, as distribuições granulométricas indicaram a preponderância de solos arenosos, sendo retidas consideráveis massas do total de $100 \mathrm{~g}$ nas peneiras de $30 \mathrm{~mm}$ e $40 \mathrm{~mm}$ e classificados como areia grossa e média (Tabela 3).

Tabela 3. Ensaios de granulometria e Teor de Umidade.

\begin{tabular}{|c|c|c|c|c|c|c|c|c|}
\hline \multicolumn{9}{|c|}{ Peneiras (mm) } \\
\hline Amostras & 10 & 30 & 40 & 60 & 120 & 270 & Prato & $\begin{array}{c}\text { Umidade } \\
(\%)\end{array}$ \\
\hline 1 & 11,120 & 39,083 & 11,316 & 8,502 & 6,537 & 10,03 & 1,701 & 18 \\
\hline 2 & 24,703 & 31,378 & 18,324 & 18,782 & 3,978 & 0,431 & 0,476 & 25 \\
\hline 3 & 13,374 & 39,000 & 09,266 & 18,836 & 0,741 & 9,658 & 2,019 & 32 \\
\hline 4 & 22,760 & 36,799 & 7,5410 & 14,463 & 9,259 & 5,288 & 2,101 & 36 \\
\hline 5 & 28,915 & 52,916 & 14,699 & 0,8060 & 0,103 & 0,409 & 0,085 & 22 \\
\hline 6 & 31,858 & 56,755 & 9,2390 & 0,5020 & 0,066 & 0,001 & 0,021 & 18 \\
\hline 7 & 39,417 & 55,531 & 3,2180 & 0,2273 & 0,002 & 0,077 & 0,011 & 20 \\
\hline 8 & 11,274 & 26,122 & 20,881 & 32,294 & 4,693 & 1,434 & 0,191 & 40 \\
\hline 9 & 41,381 & 38,195 & 17,099 & 1,8670 & 0,140 & 0,634 & 0,030 & 32 \\
\hline 10 & 32,119 & 55,586 & 8,833 & 0,0808 & 0,178 & 0,405 & 0,002 & 28 \\
\hline
\end{tabular}

Fonte: Dados da Pesquisa

Os ensaios granulométricos asseguraram a coerência dos dados de índice de pH e de teor de matéria orgânica no solo uma vez que os dados obtidos resultaram em solos arenosos, isto é, que concentram baixa saturação de bases $\left(\mathrm{K}^{+}, \mathrm{Ca}^{2+}, \mathrm{Mg}^{2+}\right)$ e a maior concentração de $\mathrm{H}^{+}$e $\mathrm{Al}^{3+}$ na solução do solo. Esses sais minerais quando situados em solos arenosos, são rapidamente lixiviados e concentram-se os óxidos de Fe e Al. Os óxidos em altas concentrações quando assimilados a baixas concentrações de matéria orgânica, auxiliam na diminuição do pH, assim, impedindo a formação de complexos com a $M O S$, tornando o solo altamente ácido. A curva granulométrica a seguir, demonstra a maior concentração de partículas de areia de 2,0 a 0,2 mm - classificando-as como areia grossa a média (Gráfico 1).

As propriedades químicas do solo assinaladas admitem tais interpretações fornecidas pelo estudo de Djalma Martinhão Gomes de Sousa e Edson Lobato (2004), cuja análise classifica tais solos como sendo solos arenosos típicos do bioma Cerrado - predominante na região - com baixo teor de matéria orgânica $(>8 \%)$ e, consequentemente $\mathrm{pH}$ ácido e umidade baixa. 


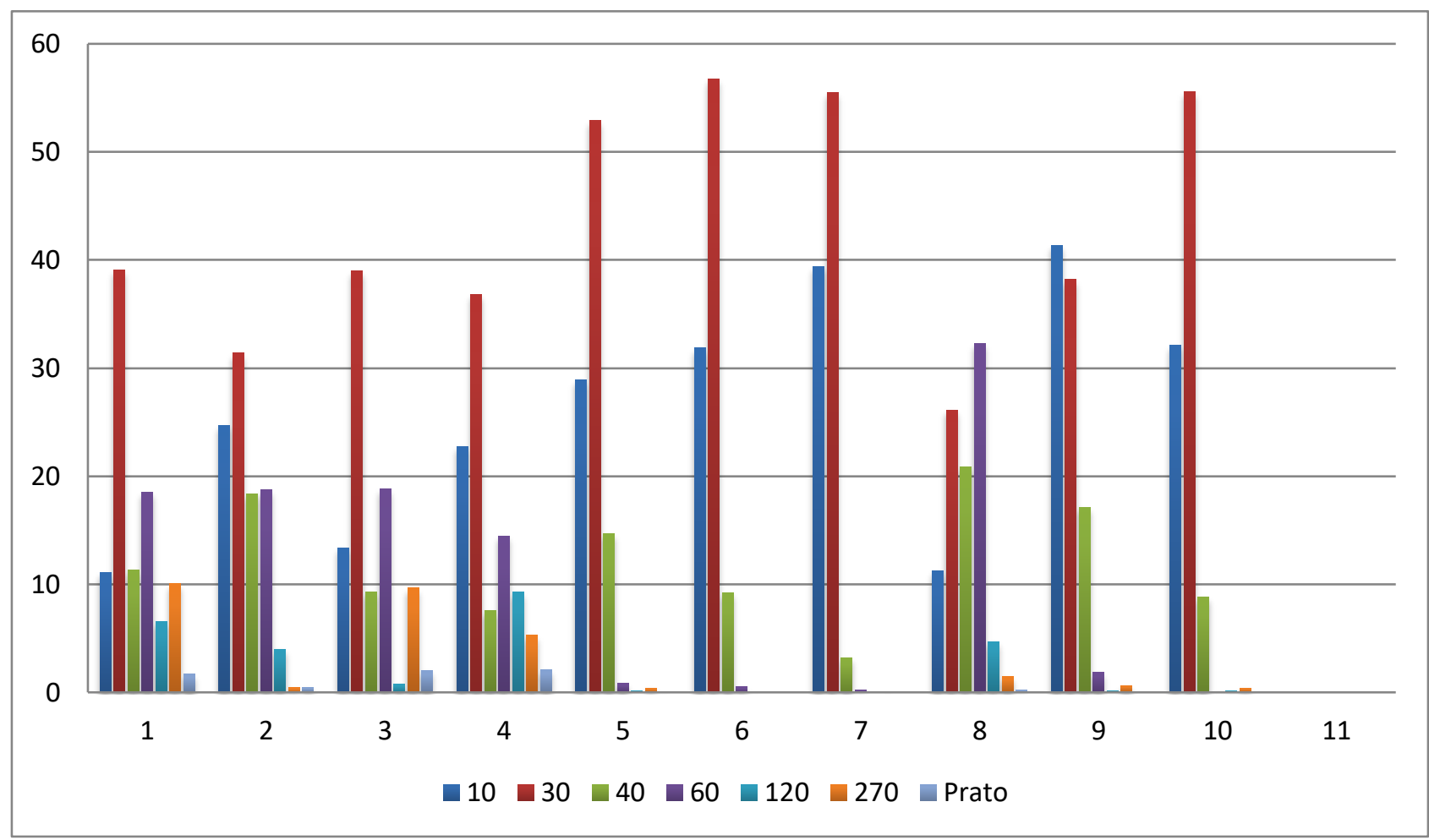

Gráfico 1. Granulometria de dez amostragens de solos coletados na pesquisa.

\subsection{MAPEAMENTO DE RECURSOS MINERAIS}

Para o levantamento de dados geológicos, fez-se necessário os trabalhos de campo. A coleta e a análise de amostras corroboraram para a verificação dos tipos de rochas presentes a partir de estudos da composição geológica e, posteriormente, viabilizou a elaboração do mapeamento de recursos minerais (Figura 6). O autor, José Eduardo Zaine (2000), elucida que os mapeamentos geotécnicos analisam conjuntamente as características de cada rocha e sua gênese, orientadas segundo as informações identificadas por toda extensão territorial, como influências endógenas e exógenas e a base geológica denotada. Para Zaine (2000), o compilado dessas informações "pode reunir os subsídios do meio físico geológico, tanto para o planejamento da ocupação futura, quanto para a correção dos problemas de natureza geológico-geotécnica instalados nos núcleos urbanos." (ZAINE, 2000, p. 4).

O mapeamento exposto aborda os recursos minerais assinalados na área delimitada pela APA do Rio Machado e seu entorno. As áreas que extrapolam o limite da APA foram às áreas que ao longo da pesquisa apresentaram características físicas relevantes ao trabalho, uma vez que problemáticas ambientais como exposição do solo, afloramentos rochosos, exposição de maciços rochosos e lavras de extração de cascalho e/ou areia contribuíram para o mapeamento. Nota-se a maior concentração de pontos coletados no trecho médio e alto da bacia e, em contrapartida, um déficit de pontos no trecho baixo (localizado próximo à jusante), isso ocorre devido aos obstáculos 
físicos que impossibilitaram o mapeamento apurado da área em questão. Os trechos médio e alto da bacia foram evidenciados pela facilidade de acesso em relação aos obstáculos naturais da paisagem e do meio urbano/rural a qual as características pertinentes ao estudo foram identificadas. Um indicativo importante são as extrações de areia, argila e areia vermelha encontradas nos trechos alto e médio, uma vez que tais atividades geram impactos ambientais negativos graves ao meio ambiente. A presença desses materiais inconsolidados é justificada pelas características geológicas da área, concomitante aos agentes intempéricos (ação pluvial, fluvial e eólica) a eles associados.

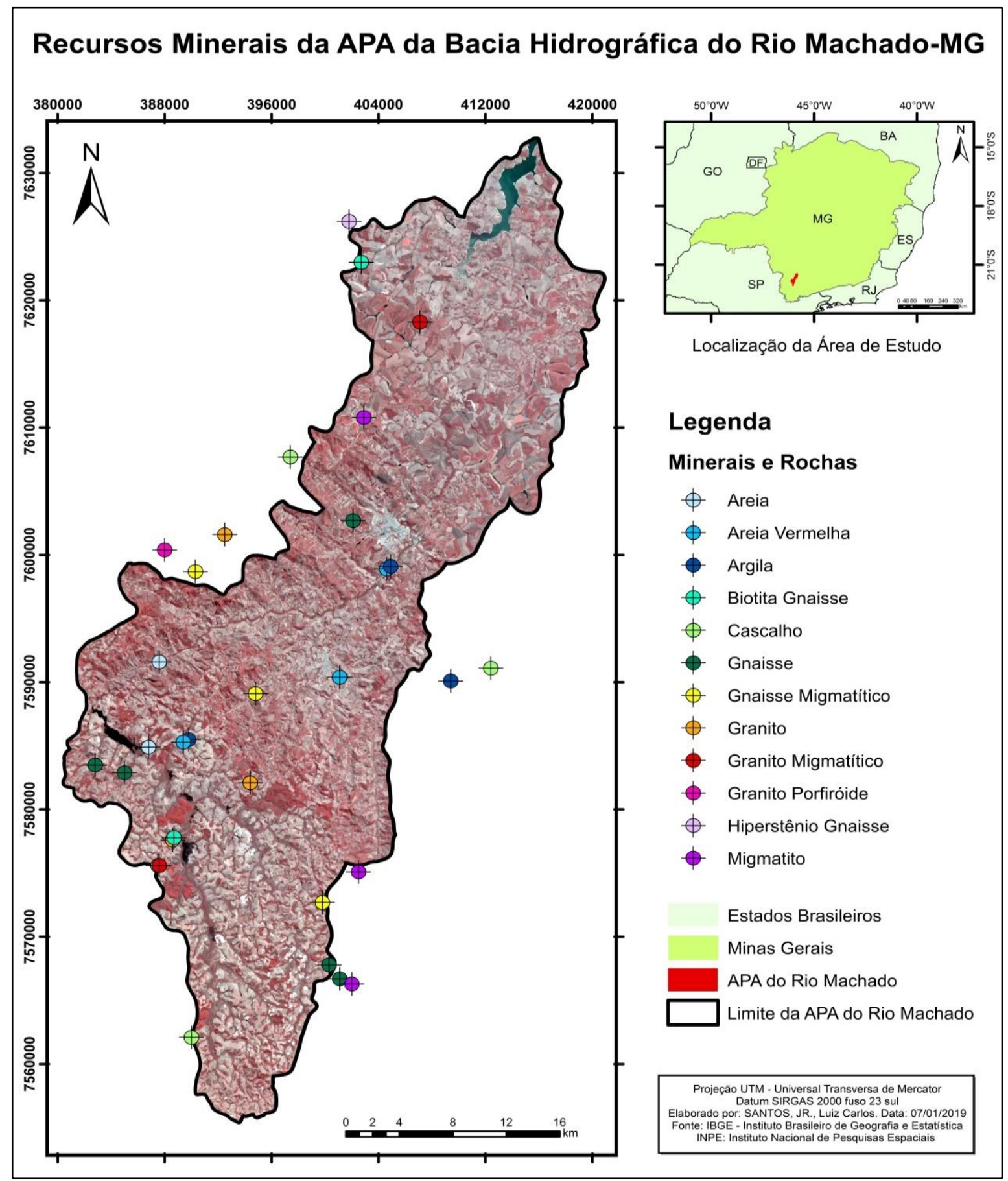

Figura 6. Mapa de Recursos Minerais da APA do Rio Machado.

Fonte: Acervo Pessoal, 2019. 
Após a identificação das rochas, foi possível relacionar a utilização das extrações com a possibilidade de irregularidades segundo o DNPM e das gestões municipais. A obtenção dos dados se dá por intermédio do desconhecimento das atividades mineradoras e sua irregularidade a partir da verificação pelo portal do DNPM e/ou através de informações adquiridas pelos órgãos municipais. Assim, foi elaborada uma tabela com os dados coletados (Tabela 4), sobrepondo os tipos de recursos minerais encontradas em campo, sua utilização e a situação de regularidade, irregularidade ou sem informação.

Tabela 4. Recursos minerais, utilização e a situação frente aos órgãos públicos.

\begin{tabular}{|c|c|c|c|}
\hline Municípios & Amostras & Utilização & Situação \\
\hline \multirow{7}{*}{ Poço Fundo } & Argila & Olaria & Sem informação \\
\hline & Areia Vermelha & Construção civil & Sem informação \\
\hline & Areia & Construção civil & Sem informação \\
\hline & Areia Vermelha & Construção civil & Sem informação \\
\hline & Gnaisse Migmatítico & $\mathrm{EP}$ & Sem informação \\
\hline & Granito Migmatítico & EP & Sem informação \\
\hline & Granito & $\mathrm{EP}$ & Sem informação \\
\hline \multirow{7}{*}{ Campestre } & Areia & Construção civil & Irregular \\
\hline & Granito Porfiróide & $\mathrm{EP}$ & Sem informação \\
\hline & Gnaisse Migmatítico & EP & Sem informação \\
\hline & Granito & EP & Sem informação \\
\hline & Gnaisse & EP & Sem informação \\
\hline & Gnaisse & EP & Sem informação \\
\hline & Gnaisse & Pedreira Ativa & Regular \\
\hline \multirow{2}{*}{ Carvalhópolis } & Argila & Dessedentação animal & Sem informação \\
\hline & Cascalho & Construção civil & Sem informação \\
\hline \multirow{2}{*}{ Alfenas } & Hiperstênio Gnaisse & Ponto turístico & Regular \\
\hline & Granada Biotita Gnaisse & Pedreira abandonada & Sem informação \\
\hline \multirow{6}{*}{ Machado } & Migmatito & $\mathrm{EP}$ & Sem informação \\
\hline & Gnaisse & EP & Sem informação \\
\hline & Cascalho & Construção civil & Sem informação \\
\hline & Areia Vermelha & Construção civil & Sem informação \\
\hline & Argila & Olaria & Regular \\
\hline & Granito Migmatítico & $\mathrm{EP}$ & Sem informação \\
\hline \multirow{5}{*}{ São João da Mata } & Migmatito & EP & Sem informação \\
\hline & Gnaisse Migmatítico & Ponto turístico & Regular \\
\hline & Cascalho & Construção civil & Sem informação \\
\hline & Gnaisse & $\mathrm{EP}$ & Sem informação \\
\hline & Gnaisse & EP & Sem informação \\
\hline \multirow{4}{*}{ Ipuiúna } & Biotita Gnaisse & EP & Sem informação \\
\hline & Granito & EP & Sem informação \\
\hline & Granito Migmatítico & EP & Sem informação \\
\hline & Biotita Granito & EP & Sem informação \\
\hline \multirow{2}{*}{ Congonhal } & Cascalho & Construção civil & Sem informação \\
\hline & Biotita Gnaisse & - & Sem informação \\
\hline $\begin{array}{c}\text { Espírito Santo do } \\
\text { Dourado }\end{array}$ & Migmatito & - & Sem informação \\
\hline
\end{tabular}


As utilizações foram classificadas segundo o tipo de extração dos recursos minerais e em função do potencial de exploração (PE) segundo a disponibilidade dos mesmos. Assim, são denominadas Olaria - para a extração de argilas; Construção Civil - para areias e cascalhos; Pontos turísticos - para os recursos minerais que envolvem o lazer; e Pedreira Ativa ou Abandonada - para aquelas que exploram ou exploraram os bens minerais. As situações de regularidades são aquelas que os órgãos públicos possuem o conhecimento da exploração e que possuem o licenciamento do DNPM; as situações irregulares são aquelas em que a extração está em pleno exercício e que não possuem o conhecimento das instâncias públicas; e as situações sem informação são aquelas em que os recursos não constam licenciamentos e não detém o conhecimento pelas prefeituras municipais.

\subsection{RISCOS AMBIENTAIS}

No que tange a definição de riscos ambientais, a literatura possui vasta concepção de "risco" e abrange diversa multidisciplinaridade de conteúdos. Entretanto, ao unir tal termo a uma abordagem ambiental, o imaginário popular pode provocar certos equívocos a respeito do tema. Dessa forma, os autores Ricardo de Sampaio Dagnino e Salvador Carpi Junior (2007), contribuem para a definição do termo ao enfatizar que "consideramos o risco como a probabilidade de que um evento esperado ou não esperado que se torne realidade. A ideia de que algo poderia vir a ocorrer, já então configura um risco" (DAGNINO; CARPI JUNIOR, 2007, p. 52). Destarte, os mesmos autores corroboram a premissa de que o risco pode se apresentar em áreas que existam a suscetibilidade ou a vulnerabilidade da ocorrência de algum tipo de impacto negativo ou de um desastre de natureza ambiental, social, cultural ou econômica. O autor Antônio Amaro (2005) ainda afirma: "o risco é o potencial de exposição da população à probabilidade de ocorrência de consequências" (AMARO, 2005, p. 7), sendo elas decorrentes de fenômenos naturais ou de atividades antrópicas.

Segundo Oswaldo Augusto Filho et al. (1990), podemos considerar que as situações de riscos ambientais são àquelas que fornecem potencialidades de perdas e danos ao homem e ao ambiente, sendo classificados como riscos naturais e antrópicos. Os riscos naturais se subclassificam em riscos físicos (riscos atmosféricos: furacões, secas, tempestades, granizo, raios etc.; geológicos: endógenos e exógenos; e hidrológicos: enchentes, inundações e alagamentos) e biológicos (associados à fauna e ou a flora). Já os riscos antrópicos podem ser tecnológicos (vazamento de produtos tóxicos, extração mineral, ocupação do solo etc.); e os riscos sociais (assaltos, guerras, conflitos, realocação, desapropriação etc.). Além disso, pode-se acrescentar aos 
riscos antrópicos a abordagem cultural (artesanato, turismo, tradições, costumes regionais etc.) e econômica (empresarial ou não em escala local, regional e/ou global).

Logo, para a presente pesquisa foi elaborado o mapeamento de riscos ambientais segundo a definição de Riscos Ambientais de Augusto Filho (1990), atribuindo maior destaque aos riscos naturais e antrópicos definidos pelo autor, correlacionando os recursos minerais identificados na área de estudo. Assim, foram classificadas em 4 (quatro) categorias, sendo elas: Risco Ambiental A (areia - retirada de leitos fluviais); Risco Ambiental B (areia vermelha e cascalho); Risco Ambiental $C$ (argila) e Risco Ambiental D (rocha ornamental - biotita gnaisse, gnaisse, gnaisse migmatítico, granito, granto migmatítico, granito porfiróide, hiperstênio gnaisse e migmatito) (Figura 7).

As categorias foram agrupadas de acordo com os riscos a eles associados. Os tipos de riscos designados foram contemplados por processos erosivos atuantes nas áreas e que puderam contribuir para o diagnóstico de Riscos Diretos, sendo eles: os movimentos de massa do tipo queda de blocos, rolamento e fluxo de terra; assoreamento de corpos hídricos e aprofundamento do leito fluvial; solos colapsíveis e expansivos; retirada de cobertura vegetal (exposição do solo) e impermeabilização do solo (pavimentação).

Os Riscos Associados são caracterizados pelos condicionantes naturais como, por exemplo, o clima; o substrato rochoso; o relevo; as águas superficiais e subsuperficiais e a vegetação, concomitante ao agravante da intervenção antrópica como, o uso e ocupação do solo (extração mineral, cultivos agrícolas, pecuária, silvicultura, mudança do curso fluvial e represamento, exposição e impermeabilização do solo). Tais ações podem afetar tanto a saúde humana como animal, proporcionando riscos sociais, econômicos, culturais e, sobretudo, ambientais (Tabela 5). 


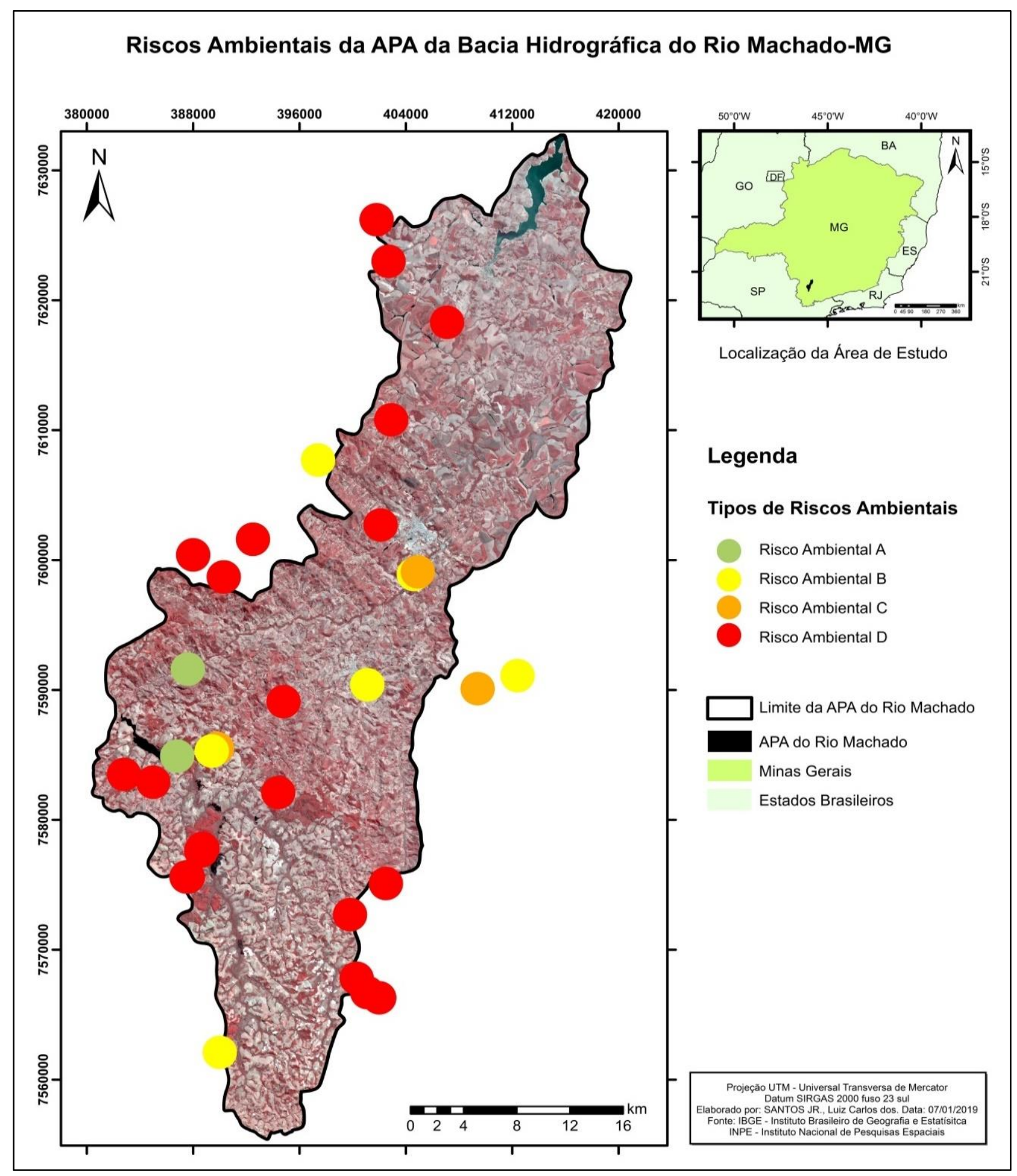

Figura 7. Mapa de Riscos Ambientais da APA do Rio Machado.

Fonte: Acervo Pessoal, 2019. 
Tabela 5. Tipos de Riscos ambientais e os riscos diretos e associados a eles.

\begin{tabular}{|c|c|c|c|}
\hline $\begin{array}{l}\text { Tipos de Riscos } \\
\text { Ambientais }\end{array}$ & Litologia & Riscos Diretos & Riscos Associados \\
\hline Risco Ambiental A & Areia & $\begin{array}{l}\text { Assoreamento de corpos } \\
\text { hídricos e aprofundamento } \\
\text { da calha fluvial. }\end{array}$ & $\begin{array}{l}\text { Perda de ictiofauna e flora; } \\
\text { abastecimento público comprometido. }\end{array}$ \\
\hline Risco Ambiental B & $\begin{array}{l}\text { Areia } \\
\text { Vermelha e } \\
\text { Cascalho }\end{array}$ & $\begin{array}{l}\text { Exposição de solo (retirada } \\
\text { de cobertura vegetal) e } \\
\text { impermeabilização do solo } \\
\text { (pavimentação da área } \\
\text { urbana). }\end{array}$ & $\begin{array}{l}\text { Perda de flora, fauna e produtividade do } \\
\text { solo; baixa capacidade de infiltração } \\
\text { pluvial e, consequentemente, enchentes. }\end{array}$ \\
\hline Risco Ambiental C & Argila & $\begin{array}{l}\text { Solos colapsíveis e } \\
\text { expansivos e fluxo de terra. }\end{array}$ & $\begin{array}{l}\text { Em altas declividades, a baixa } \\
\text { permeabilidade do solo contribui para o } \\
\text { fluxo de terra; em baixas declividades } \\
\text { há interferência na dinâmica fluvial. }\end{array}$ \\
\hline Risco Ambiental D & $\begin{array}{c}\text { Rocha } \\
\text { Ornamental }\end{array}$ & $\begin{array}{l}\text { Queda de blocos e } \\
\text { rolamento. }\end{array}$ & $\begin{array}{l}\text { Em altas declividades, os afloramentos } \\
\text { rochosos estão associados a imóveis } \\
\text { rurais e atividades agrosilvipastoris } \\
\text { (risco econômico, social e ambiental). }\end{array}$ \\
\hline
\end{tabular}

O mapeamento de recursos minerais associado ao de riscos ambientais pode contribuir para o planejamento urbano e rural, uma vez que os danos decorrentes da exploração mineral irregular geram impactos negativos na população e no seu entorno. Os maior risco diagnosticado pelo estudo foi a exposição do solo por aberturas de taludes artificiais para retirada de areias e cascalhos, agravadas pela compactação do solo pelo gado em áreas de pastagens. A exposição do solo e a posterior compactação resultam em erosões lineares, podendo evoluir para voçorocas - dada a própria suscetibilidade dos solos arenosos identificados no estudo. A identificação da disponibilidade dos bens minerais auxiliará na elaboração do Plano Diretor da Área de Proteção Ambiental e de estratégias que visem a prevenção de impactos ambientais irreversíveis ao apontar os riscos decorrentes da extração mineral ilegal. Assim, os danos diretos poderão ser erradicados e estarão sob constante monitoramento das diretrizes dos governos municipais e federais através da gnose de informações obtidas pelo presente estudo.

\section{CONSIDERAÇÕES FINAIS}

Embora o mapeamento seja conciso e evidencie os tipos de minerais e rochas presentes nos municípios visitados, às informações obtidas ainda são limitadas. Os dados subsidiados pela pesquisa ficaram sujeitos aos obstáculos naturais e antrópicos como, por exemplo, estradas desativadas, vegetação densa, terreno íngreme e propriedades particulares que dificultaram o acesso. O desconhecimento da ilegalidade ou a quantidade exata de empresas que exploram os recursos minerais carecem de consultas mais acuradas através das gestões municipais e dos dados disponibilizados pela plataforma digital do CPRM (Companhia de Pesquisa de Recursos Minerais). 
Destarte, os dados adquiridos pelo projeto, fornecem importantes constatações ao DNPM, prefeituras e servirá de apoio teórico-técnico para estudos e intervenções futuras.

Ademais, os riscos ambientais assinalados pelas mineradoras irregulares identificadas pela pesquisa sugerem a perda da fauna e flora, o comprometimento do abastecimento público e dessedentação animal por rejeitos da mineração lançados em afluentes; a perda da produtividade do solo; a impermeabilização do solo; movimentos de massa; assoreamento de corpos hídricos e mudanças na dinâmica fluvial; e a exposição de solos que acarretará erosões lineares, ocasionando impactos negativos diretos no âmbito social, econômico, cultural e ambiental da região.

\section{REFERÊNCIAS}

AMARO, A. Consciência e cultura do risco nas organizações. Territorium, Coimbra, v. 1, n. 12, p. $5-9,2005$.

AUGUSTO FILHO, O.; CERRI, L.E.S.; AMENOMORI, C. J. Riscos geológicos: aspectos conceituais. In: SIMPÓSIO LATINO-AMERICANO SOBRE RISCO GEOLÓGICO URBANO. I., 1990, São Paulo. Anais... São Paulo: ABGE, 1990. p.334-341.

BARBOSA, B.; FERREIRA, N.; BARRA, A. Importância da geologia na defesa do património geológico, no geoturismo e no ordenamento do território. Revista da Associação Portuguesa de Geólogos, São Mamede de Infesta, v. 1, n. 13, p. 22-33, 1999.

DAGNINO, R. de S.; CARPI JUNIOR, S. Risco Ambiental: Conceitos e Aplicações. Revista de Climatologia e Estudos de Paisagem, Rio Claro, v. 2, n. 2, p. 50-87, 2007.

EMBRAPA - Empresa Brasileira de Pesquisa Agropecuária. Manual de Métodos de Análise de Solo. Brasil, 2018. Disponível em: https://www.infoteca.cnptia.embrapa.br/bitstream/doc/990374/1/ ManualdeMtodosdeAnilisedeSolo.pdf. Acesso em: 06 jan 2018.

GASPAR, L. A. G. J. Geologia Ambiental: Ensaios Químicos e Geotécnicos em Solos. 1. ed. Alfenas: UNIFAL, 2011. 57p.

IEF- Instituto Estadual de Florestas-MG. Áreas Protegidas. Área de Proteção Ambiental. Brasil, 2018. Disponível em: http://www.ief.mg.gov.br/images/stories/2018/UNIDADES_DE CONSERVA\%C3\%87\%C3\%83O/APAS_26062018.pdf. Acesso em: 06 jan 2018.

LIMA, H. C.; DORANTI, C.; HACHSPACHER, P. C.; RIBEIRO, M. C. S.; BRANDINI RIBEIRO, L. F. Análise morfométrica da rede de drenagem da bacia do Rio do MachadoMG. Sociedade \& Natureza, São Paulo, v. 22, n. 1, p. 23-34, 2010.

ROSS, J. L. S.; DEL PRETTE, M. E. Recursos Hídricos e as Bacias Hidrográficas: Âncoras do Planejamento e Gestão Ambiental. Revista do Departamento de Geografia, São Paulo, v. 12, p. 89-121, 2011.

SÁNCHEZ, L. E. Avaliação de Impacto Ambiental: Conceitos e métodos. 2. ed. São Paulo: Oficina de Texto, 2006. 496p. 
SERVIDONI, L. E.; SANTOS, C. A. Análise Morfométrica do Rio Machado por meio de Krigagem Ordinária em Sistema de Informação Geográfica. In: COLÓQUIO DE GEOGRAFIA FÍSICA E GEOTECNOLOGIAS, I., 2014, Alfenas. Anais... Alfenas: UNIFAL, 2014. p. 40.

SOUSA, D. M. G.; LOBATO, E. Cerrado: correção do solo e adubação. 2. ed. Brasília: EMBRAPA, 2004. 416p.

VEYRET, Y.; RICHEMOND, N. M. O risco: Definições e vulnerabilidades do risco. In: VEYRET, Y. Os riscos: o homem como agressor e vítima do meio ambiente. São Paulo: Contexto, 2007. Cap. 2, p. 23-80.

ZAINE, J. E. Mapeamento geológico-geotécnico por meio do método do detalhamento progressivo: ensaio de aplicação na área urbana do Município de Rio Claro (SP). 2000. 189 f. Tese (Doutorado) - Instituto de Geociências e Ciências Exatas, Universidade Estadual Paulista, Rio Claro, 2000.

Trabalho enviado em 25/05/2019

Trabalho aceito em 25/06/2019 